\title{
Eleusine indica (L.) Gaertn., new species of the adventive flora of Slovakia
}

\author{
Zuzana Dítě ${ }^{1}$, Daniel Dítě ${ }^{1} \&$ Viera Feráková2 \\ ${ }^{1}$ Institute of Botany, Plant Science and Biodiversity Center, Slovak Academy of Sciences, \\ Dúbravská cesta 9, SK-845 23, Bratislava, Slovakia zuzana.dite@savba.sk \\ ${ }^{2}$ Karloveská 23/43, 84104 Bratislava
}

\begin{abstract}
Dítě Z., Dítě D., Feráková V. (2019): Eleusine indica (L.) Gaertn., new species of the adventive flora of Slovakia. - Thaiszia - J. Bot. 29 (1): 077-084.

Abstract: First two records of Eleusine indica in Slovakia are presented. This exotic grass species originating from the tropical Old World was found in the Podunajská nížina Lowland (Eupannonicum): in 2017 in Štúrovo and the next year in Bratislava, municipal part Karlova Ves. Both populations counted only three individuals grown in the pavement cracks. The habitat conditions of each locality in detail are characterized. Whereas Slovakia is among the last countries where $E$. indica was just discovered within Europe, we discuss the environmental conditions and the origin of the species in the backlight of earlier studies related to its occurrence in the surrounding countries.

Key words: urban ecosystems, roadsides, new record, Eleusine indica, casual alien, plant invasion
\end{abstract}

\section{Introduction}

Eleusine indica is a late summer annual grass. Its long, spreading spikes resemble goose feet. Confusion with other grasses of digitate inflorescence (e.g. with Digitaria or Cynodon) is possible, but $E$. indica 's flattened culms, bright green leaves, size of many-flowered spikelets, and lack of awns serve to distinguish (Clayton et al. 2006). 
The geographical origin of E. indica is uncertain due to its worldwide expansion, but it is considered native to the tropical regions of the Old World (Eastern Africa). This exotic grass is naturalized in Portugal (incl. Azores), Spain, France, Italy and it is casual in Great Britain, Netherlands, Austria, Croatia, Slovenia, Hungary, Serbia, Romania and Bulgaria (Hansen 1980). It is listed as fifth among the ten worst word's weeds as a serious, dominant agricultural weed (Holm et al. 1977). E. indica occuppies in Europe disturbed habitats such as roadsides and fields. The most frequently is reported in urban areas (e.g. pavements, parking lots, dump stations).

There are no any published data or mention of E. indica in Slovakia (Medvecká et al. 2012). As a strong competitor species, it is a member of the casual adventive flora of the surrounding countries. In the Czech Republic the first record was published by Dvořák \& Kühn (1966), under the synonym E. japonica. It was found in 1963 near Brno in the gardening colony among other ruderal plants growing on the fertilized soils originating from the sludge after cleaning Australian raw wool in the nearby factory Mosilana. A later record from the Rybárska Street from the outskirts of Olomouc (in 1984) due to its incorrect determination was stored under the genus Digitaria (Kubát 2008). Other specimens found between years 1974 and 1998 around food factories in Kolín and Ústí nad Labem are related to oil and soy production imported from abroad (Jehlík 1998). Otherwise, it is not the only species of the genus occurring in the Czech Republic, as some of the older records of. E. indica were determined to E. coracana (also an annual plant, grown for grain) and to E. tristachya (Kaplan 2014).

Similarly in Austria, where the perennial E. tristachya is also present, E. indica is known from 1969. Today it spreads in the eastern and south-eastern regions of the country. It has rich stands in Vienna: e.g. at several micro-sites around the large building of the Museum of Natural History, on a trash dump at the Schwechat Airport, and it is also reported in Steiermark, along the track at the grain silo (Wallnöfer 2014).

In Poland the species was firstly recorded in the 1930s (Urbisz 2011); in Szczecin at garbage dump near the oil mill and on field verges, recent record is in Katowice from roadsides (p. 131 from Urbisz I.c.).

In Hungary the first observation of E. indica was reported by Polgár (1918) from Győr and later from other larger cities such as Budapest (Pénzes 1929), Szeged (Timár 1948), Debrecen (Pfeiffer 1998), as well as in smaller settlements like Budakalász or Esztergom (Barina \& Schmidt 2004). Recently it is massively expanded in several regions throughout the country (Dancza 2012) and according to the latest detailed study dealing with its gradual expansion and coenological 
preferences, it occurs in all districts of Budapest, locally in very rich populations (Csontos et al. 2017).

Such naturalizing process is in the southern contries of Europe, e.g. in Romania, where the first report of $E$. indica was from laşi in 1957 via seeds of Lolium perenne used for lawns. To the invasive capacity of the species due to its large distribution in the country (Ciocârlan 2009) noticed Culitâ et al. (2011). Similar wide-spread distribution is in Croatia (Pandža et al. 2001) where in the 1970s E. indica had four distant localities in inland and coastal regions as well (Topić \& Šegulja 1978).

Whereas Slovakia is one of the last European countries where Eleusine indica has just appeared (or has been noticed), we summarize and compare the environmental conditions and the origin of the species taking into account other studies published from the surrounding countries dealing with its various occurrences.

\section{Material and Methods}

The studied plant species, Eleusine indica (L.) Gaertn (family Poaceae) is a caespitose, annual species. Its habit is prostrate and spreading , culms ascending or erect to about $40 \mathrm{~cm}$. Leaves are glabrous and bright, fresh green in colour. Ligule is a very short membraneous rim up to $1 \mathrm{~mm}$ long, sparsely fringed with short hairs. Sheaths and stem bases are distinctly flattened. The inflorescence consists of 3-8 racemes, each 5-10 cm long, about $5 \mathrm{~mm}$ wide, arranged more-orless digitately, though one raceme may be inserted about $1 \mathrm{~cm}$ below the others. Narrow rachis, about $1 \mathrm{~mm}$, has two dense rows of almost glabrous spikelets, each 2.5-3 mm long, 3-5 flowered, the lower and upper glumes about 1.5 and 3 $\mathrm{mm}$ long, respectively, and the lemmas very similar in both texture and size to the upper glume. All have a slightly scabrid keel and are acute but not awned. The reddish-brown to black seeds are oblong, about $1 \mathrm{~mm}$ long, conspicuously ridged (Clayton et al. 2016).

Field observations were conducted in several times between February, 2017 and September, 2018 in the towns of Bratislava and Štúrovo. The collected voucher specimens of Eleusine indica are deposited in the herbarium of the Slovak Academy of Sciences (SAV). Quadrant numbers are given according to the Central European Flora Mapping System (Niklfeld 1971). The phytogeographical classification of Slovakia is considered according to the work of Futák (1984). Nomenclature of flowering plants follows Marhold (1998). 


\section{Results}

Even though Eleusine indica has been known for a long time in the Czech Republic Austria and Hungary, in Slovakia it was discovered only in 2017. We have found it in the town of Štúrovo on the Széchenyiho street near the Bridge of Mária Valéria leading to Hungary (Podunajská nížina, 8278a). The population counted three individuals (two bigger and one small) growing on the edge of the pavement between the curb and the lawn. Although the time of the first record (February) was out of the vegetation season, the shrivelled fertile plants from the previous year were easily determinable (Fig.1, left picture). In the vegetation period in 2017 we have not found any specimen, only in 2018, when two individuals were observed on the same place (Fig. 1, right picture). The surrounding accompanying species were Poa annua, P. compressa, Trifolium repens, Cynodon dactylon, Lamium purpureum, Taraxacum sect. Ruderalia, Capsella bursa-pastoris and Erodium cicutarium, many of them typical to the trampled vegetation of the class Polygono arenastri-Poetea annuae Rivas-Mart. 1975 corr. Rivas-Mart. et al. 1991 (Jarolímek et al. 1997).

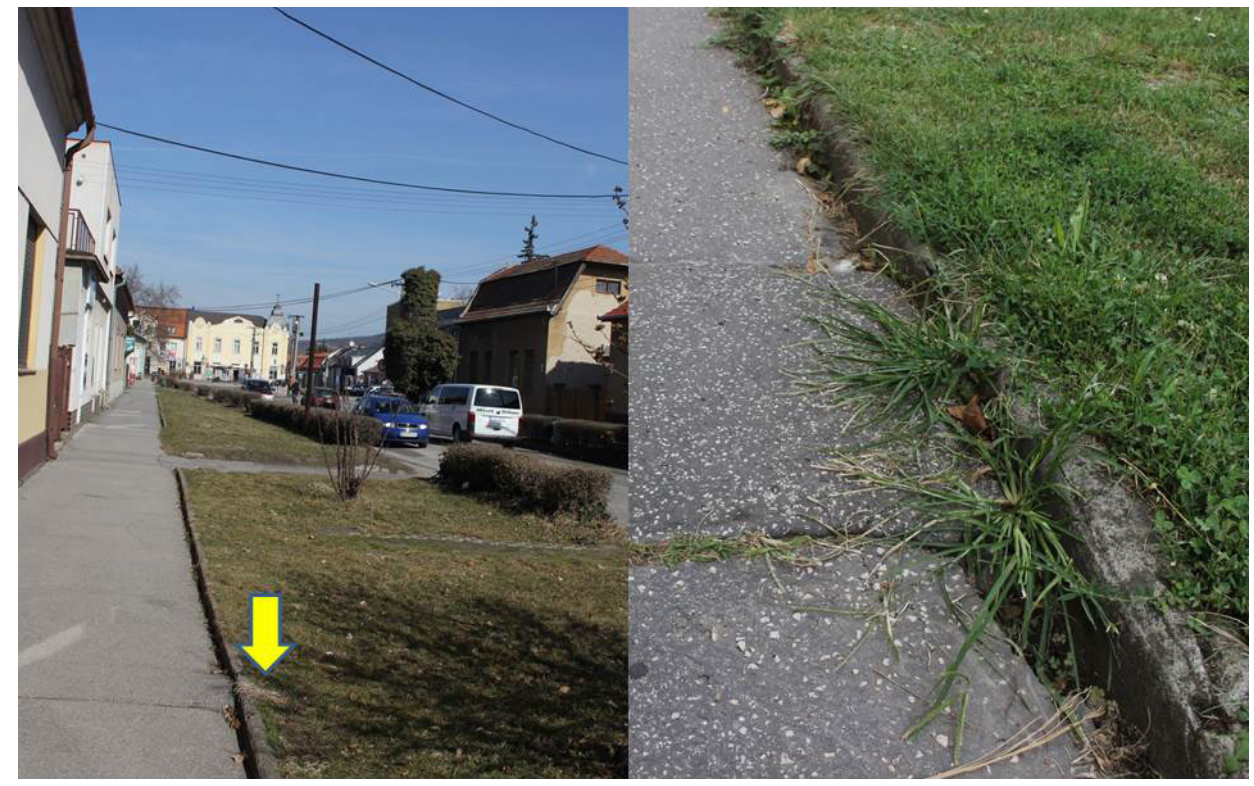

Fig. 1. Eleusine indica in Štúrovo, Széchenyi Street (4. 3. 2017 and 27. 7. 2018, Daniel Dítě).

The second site of Eleusine indica in Slovakia has been found in May 2018 in Bratislava, municipal part Karlova Ves, Karloveská street (Podunajská nížina, 
7868a), on the edge of pavement, close to the back entrance No. 21 of the block of flats (Fig.2). Two flowering plants most probably originated from the seeds of bird's food from the cage situated on the nearby balcony, similarly as one plant of Panicum miliaceum. In the close vicinity of the habitat of $E$. indica there was a large population of Commelina communis, which is widely spreading in the neighbouring plots. On the adjacent neglected flower bed were recorded wild growing species: Amaranthus lividus, Portulaca oleracea, Poa annua, Setaria pumila, Stellaria media, Erodium cicutarium, Capsella bursa-pastoris, Rumex patientia.

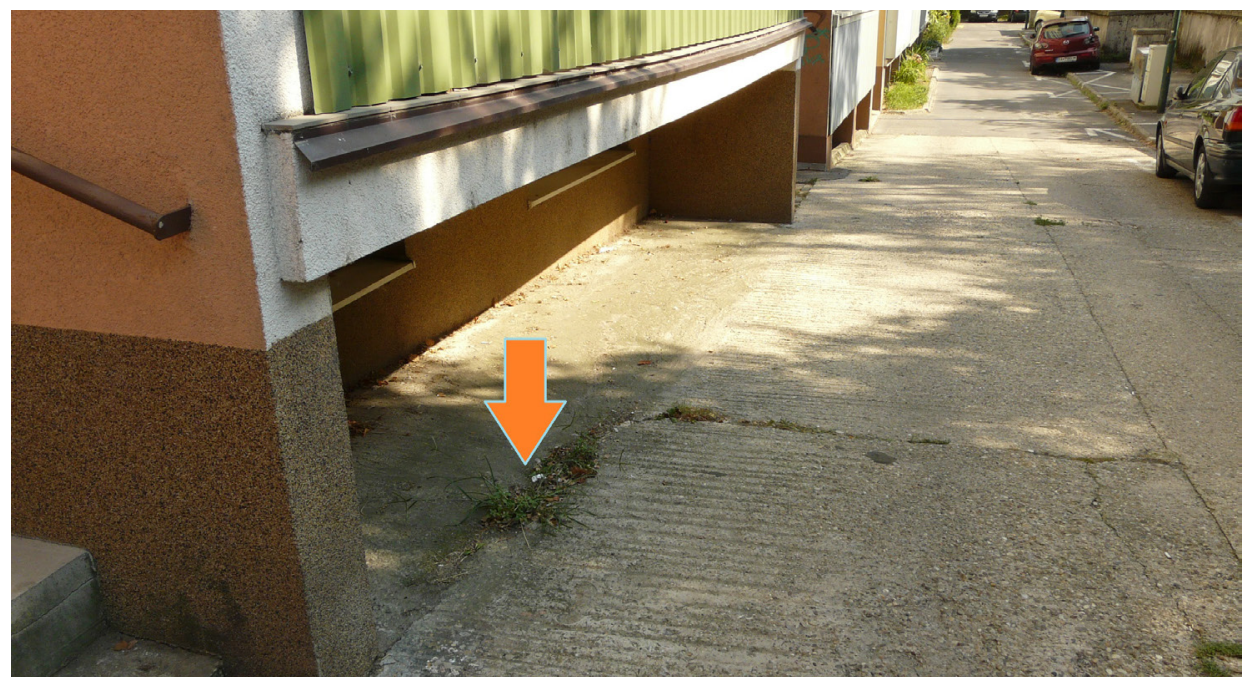

Fig. 2. Eleusine indica in Bratislava, Karloveská Street (28. 5. 2018, Pavol Mered’a jun.).

\section{Discussion}

As the origin of the new stand of $E$. indica in Štúrovo we consider the closest known site in the neighbouring town Esztergom, Hungary. There were recorded a few individuals in pavement crevices (Barina \& Pifkó 2007) near the bus station of the town. In August, 2018, during a detailed observation of the surrounding streets published in the above mentioned work, we have found hundreds of fertile individuals in the same habitat circumstances, other preferable places were the gaps between the cobble stones. The occurrence in Štúrovo might be the result of the traffic revival between Esztergom and Štúrovo after the reopening the Mária Valéria Bridge in 2001. Due to the impermanent presence it is not excluded that $E$. indica was there (or elsewhere) earlier. 
E. indica in Central Europe occurs outside of urbanized areas as well, in more natural conditions. We have recorded it in the exposed, gravel-sandy banks of the Danube river in Esztergom, Szentgyörgymező in periodically flooded ruderalized vegetation (Dítě \& Dítě 2018, ined.). This is not the only known natural habitat of the species in Hungary, there are similar observations as well (Barina \& Schmidt 2004).

Another recent example of its escape into the wild was reported by Sádlo \& Marek (2018) in the Czech Republic. The latest major summer floods of the Vltava River in 2013 resulted a rapid development of thermophilous exotic species on the fine river sediments around Prague; among E. indica were found for instance Chenopodium quinoa or Salvia hispanica (known as chia seeds) popular representatives of the today's healthy diet. Their field observations (Sádlo \& Marek 2018) confirmed that these species together with E. indica can be abundant in localities where fallen seed mixture remains on the ground, e.g. under the balconies with parrot feeding. The second record of E. indica in Bratislava described above is a very similar case.

In Slovakia, we asses the invasion status of $E$. indica is casual. All occurrences of $E$. indica in Central Europe are related to food processing and storage (rather earlier records before 1980) or transportation (rather recent cases), the natural way of spreading (e.g. along river beds) is less common yet. Taking into account the experiences from other countries, the spread of alien weeds in a larger extent is expectable in the future. In Slovakia, some thermophilic weeds (Dittrichia graveolens and Euphorbia prostrata) have already appeared in larger towns or motorways thanks to the local heat effect (Király et al. 2014). These attempts are not always succsessful, since the majority of late summer exotic newcomers are often being recorded only once then they rapidly disappear, since they are unable to produce seeds due to the cooler climate in the late growing season in Central Europe (Frey 2010; Csontos et al. 2017; Sádlo \& Marek 2018). Nevertheless, spontaneous occurrence and naturalization of invincible weeds outside of man-made habitats is going to be a general phenomenon, not only due to the increasing traffic. The higher mean and extreme temperatures measured in the latest years provide also better life conditions for them.

\section{Acknowledgements}

Our thanks are due to Zoltán Barina (Budapest), Dávid Schmidt (Sopron), Pavol Mered'a jun. (Bratislava) and Vít Grulich (Brno) for providing their field observations and providing some literature resources. The study was conducted within the grant no. VEGA 2/0040/17. 


\section{References}

Barina Z. \& Pifkó D. (2007): Botanikai kutatások a Visegrádi-hegységben. - Kitaibelia 12/1: 9-25.

Barina Z. \& Schmidt D. (2004): A Duna medrének iszapnövényzete. „Aktuális flóra és vegetációkutatás a Kárpát-medencében VI." konferencia, 2004. február 2629, kötet, p. 38. - Veszprémi Egyetem Georgikon Mezőgazdaságtudományi Kar, Keszthely.

Ciocârlan V. (2009): Flora Ilustrata a Romaniei Pteridophyta et Spermatophyta. - Edit. Ceres, Bucureşti, 1142 p.

Clayton W. D., Vorontsova M. S., Harman K. T. \& Williamson H. (2006 onwards). GrassBase - The Online World Grass Flora. https://www.kew.org/data/ grassbase/

Csontos P., Mjazovszky Á., Tamás J. \& Dancza I. (2017): Az aszályfű (Eleusine indica) elterjedtségének és társulástani viszonyainak vizsgálata Budapesten. - Bot. Közl. 104/2: 213-234. DOI: 10.17716/BotKozlem.2017.104.2.213

Culitâ S., Oprea A., Eliáś P. jun. \& Ferus P. (2011): New contribution to the study of alien flora in Romania. - J. Plant Develop. 18: 121-134.

Dancza I. (2012): Aszályfű (Eleusine indica). - In: Csiszár Á. (ed.): Inváziós növényfajok Magyarországon, p. 331-334. - Nyugat-magyarországi Egyetem Kiadó, Sopron.

Dvořák J. \& Kühn F. (1966): Eingeschleppe Pflanzen im Areal der Wollspinnerei 'Mosilana' in Brno (Brünn). - Preslia 38: 327-332.

Frey L. (2010): Grasses in Poland: invincible, but threatened. - Biodiv. Res. Conserv. 19: 93-102. DOI: 10.2478/v10119-010-0025-z

Futák J. (1984): Fytogeografické členenie Slovenska. - In: Bertová L. (ed.), Flóra Slovenska IV/I, p. 418-420. - Veda, Bratislava.

Hansen A. (1980): Eleusine Gaertner. - In: Tutin T.G. et al. (eds.): Flora Europaea V., p. 258-259. - Cambridge University Press, Cambridge.

Holm L. R. G., Plucknett D. L., Pancho J. V. \& Herberger J. P. (1977): The world's worst weeds. Distribution and biology. - University Press of Hawaii Honolulu, Hawaii USA.

Jarolímek I., Zaliberová M., Mucina L., Mochnacký S. (1997): Rastlinné spoločenstvá Slovenska 2. Synantropná vegetácia. - Veda, Bratislava. Vydavatel'stvo SAV, Bratislava. $416 \mathrm{pp}$.

Jehlík V. [ed.] (1998): Cizí expanzivní plevele České republiky a Slovenské republiky. - Academia, Praha.

Kaplan Z. (2014): Eleusine. - In: Hadinec J. \& Lustyk P. (eds.): Additamenta ad floram Reipublicae Bohemicae. XII. - Zprávy Čes. Bot. Společ., Praha, 49: 114-117. 
Király G., Eliáš P. jun. \& Dítě D. (2014): Two thermophilic alien species new to the flora of Slovakia. - Thaiszia - J. Bot., 24: 125-134.

Kubát K. (2008): Eleusine indica (L.) Gaertn. - In: Hadinec J. \& Lustyk P. (eds.): Additamenta ad floram Reipublicae Bohemicae. VII. - Zprávy Čes. Bot. Společ., Praha, 43: 273.

Marhold K. (ed.) 1998. Ferns and Flowering plants. - In: Marhold K. \& Hindák F. (eds.), Checklist of non-vascular and vascular plants of Slovakia, p. 333-687. - VEDA, Bratislava.

Medvecká J., Kliment J., Májeková J., Halada L'., Zaliberová M., Gojdičová E., Feráková V. \& Jarolímek I. (2012): Inventory of the alien flora of Slovakia. Preslia 84: 257-309.

Niklfeld H. (1971): Bericht über die Kartierung der Flora Mitteleuropas. - Taxon 20: 545-571. DOI: 10.2307/1218258

Pandža M., Franjić j., Trinajstić I., Škvorc Ž. \& Stančić Z. (2001): The most recent state of affairs in the distribution of some neophytes in Croatia. - Nat. Croat. 10/4: 259-275.

Pénzes A. (1929): Eleusine indica (L.) Gaertn., Budapest új behurcolt növénye. Magyar Bot. Lapok 27: 113.

Pfeiffer N. (1998): Eleusine indica (L.) Gärtn.: Debrecenben és Szulokon. Kitaibelia 3/2: 371.

Polgár (1918): Neue Beiträge zur Adventivflora von Győr (Westungarn). - Magyar Bot. Lapok 17: 27-41.

Sádlo J. \& Marek M. (2018): Salvia hispanica L. - In: Lustyk P. \& Doležal J. (eds.): Additamenta ad floram Reipublicae Bohemicae. XVI. - Zprávy Čes. Bot. Společ., Praha, 49: 42-46.

Timár L. (1948): A Tisza- és Marosmente új növényei. - Borbásia 8: 58-61.

Topić J. \& Šegulja N. (1978): Novo nalazište vrste Eleusine indica (L.) Gaertn. u Hrvatskoj. - Acta Bot. Croat. 37: 229-230.

Urbisz A. (2011): Occurrence of temporarily-introduced alien plant species (ephemerophytes) in Poland - scale and assessment of the phenomenon. Wydawnictwo Uniwersytetu Śląskiego, Katowice.

Wallnöfer B. (2014): Über die Verbreitung von Eleusine indica und E. tristachya (Gramineae) in Österreich. - Ann. Nat. Hist. Mus. Wien Ser. B Bot. Zool. 116: 181-190. 